\title{
Antifungal prophylaxis in stem cell transplantation centers in Turkey
}

\author{
Türkiye'deki kök hücre nakli merkezlerinde antifungal profilaksi
}

\author{
Hamdi Akan \\ Department of Hematology, Faculty of Medicine, Ankara University, Ankara, Turkey
}

\begin{abstract}
Objective: This study aimed to determine the current state of antifungal prophylaxis in Turkish stem cell transplantation (SCT) centers.

Materials and Methods: The were 38 active stem cell transplantation centers in Turkey, 28 of which were registered with the European Group for Blood and Marrow Transplantation (EBMT). Survey questionnaires were sent to the 28 EBMT centers in an effort to collect data on antifungal prophylaxis in different settings. In all, 24 of the centers completed the survey; 1 of the 24 centers was excluded from the study, as it was under construction at the time and was not performing transplantation.

Results: In all, 15 (65\%) of the 23 centers were adult SCT centers, 7 (31\%) were pediatric SCT centers, and 1 center treated both adult and pediatric patients. All centers (23/23) performed both allogeneic and autologous transplants, 20 centers performed non-myeloablative transplants, 8 performed cord blood transplants, and 7 performed unrelated transplants. Primary antifungal prophylaxis was used at all 23 centers during allogeneic transplants, whereas 18 of the 23 centers used it during every autologous transplant and 2 of the 23 centers used it during autologous transplants on a per case basis. The most common drug used for prophylaxis was fluconazole (F) (21/23), followed by itraconazole (I) (3/23), amphotericin-B (2/23), and posaconazole (1/23). Among the 23 centers, 3 reported that for allogenic transplants they changed the antifungal prophylactic in cases of graft versus host disease (GVHD), and 12 of the 23 centers reported that they changed the antifungal prophylactic in case of nearby construction. All 23 centers performed secondary prophylaxis.

Conclusion: Antifungal prophylaxis for hematopoetic SCT patients was the standard protocol in the 23 centers included in the study, usually with such azoles as $F$. The introduction of posaconazole in Turkey and the potential approval of voriconazole for antifungal prophylaxis will eventually alter prophylaxis practice in Turkey, which we plan to assess in the future. (Turk J Hematol 2011; 28: 271-5)

Key words: Prophylaxis, antifungal, stem cell transplantation
\end{abstract}

Received: February 28, 2011

Accepted: June 1, 2011

Özet

Amaç: Türkiye'deki kök hücre nakli merkezlerinde antifungal profilaksi eğilimlerini anlamak için yapılan bu çalışma bir anket çalışmasıdır.

Address for Correspondence: Prof. Hamdi Akan, Department of Hematology, Faculty of Medicine, Ankara University, 06590 Ankara, Turkey Phone: +90 3125957342 E-mail: akan@medicine.ankara.edu.tr

doi:10.5152/tjh.2011.81 


\begin{abstract}
Yöntem ve Gereçler: Türkiye'de çalışan 38 kök hücre nakli merkezinden EBMT'ye kayıtlı 28 merkeze anket gönderilmiş ve $\mathbf{2 4}$ merkezden yanıt alınmıştır. Bir merkez halen inşaat yapımı nedeni ile anketi dolduramamıştır.

Bulgular: Bu merkezlerden 15 tanesi erişkin (\%65), 7 tanesi çocuk (\%31) ve 1 tanesi erişkin ve çocuk nakil merkezidir. Tüm merkezler hem allogeneik, hem de otolog nakil yapmakta olup; 20 merkezde nonmyeloablatif, 8 merkezde kordon kanı ve 7 merkezde akraba dışı nakil yapılmaktadır. Tüm merkezlerde allogeneik nakillerde profilaksi yapılırken, 18/23 merkezde otolog nakillerde profilaksi yapılmaktadır. 23 merkezden 2'si ise, otolog nakilde olguya göre profilaksi vermektedir. En çok kullanılan ajan Flukonazol olup (21/23), bunu Itrakonazol (3/23), amfoterisin-B (2/23), ve posakonazol (1/23) izlemektedir. Allogeneik nakil yapılan 3 merkez Graft versus Host Hastalığı varlığında profilaksiyi değiştirmekte ve 12/23 merkez yakında inşaat olması durumunda profilaktik yaklaşımlarını değiştirmektedir. Tüm merkezler sekonder profilaksi yapmaktadır.

Sonuç: Son yıllardaki gelişmeler bu alandaki yaklaşımları değiştirecek ve Flukonazol yerine yeni triazollerin geçmesine yol açacak niteliktedir. Bu nedenle bu anket 2013 yılında yinelenerek değişim olup olmadığı anlaşılacaktır. (Turk J Hematol 2011; 28: 271-5)
\end{abstract}

Anahtar kelimeler: Profilaksi, antifungal, kök hücre nakli

Geliş tarihi: 28 Şubat 2011

Kabul tarihi: 01 Haziran 2011

\section{Introduction}

The results of a recent survey by the Worldwide Network for Blood and Marrow Transplantation show that in 2008 more than 51,000 hematopoietic stem cell transplantations (HSCTs) were performed by 1400 teams in 72 countries. In Turkey 944 HSCTs were performed in 2010 (numbers reported by 19 European Group for Blood and Marrow Transplantation [EBMT] centers); 561 were autologous and 383 were allogeneic HSCTs, and 97 were non-myeloablative transplants.

HSCT is a lifesaving technique, especially in the treatment of hematological malignancies; however, it is associated with a high risk of infections. Fungal infections are a major problem and although they represent a small fraction of the infection spectrum, they are associated with a high risk of mortality [1-3]. In recent years new methods of treating invasive fungal infections have been developed, but they are time consuming, expensive, and have a high risk of severe side effects. Although evidence of the benefit of antifungal prophylaxis in the treatment of malign hematological diseases is weak, there is sufficient evidence of the positive effect of antifungal prophylaxis on morbidity and mortality in stem cell transplantation (SCT) [4-6].

Fluconazole $(F)$ has been the main agent used for antifungal prophylaxis against Candida infections, but it is ineffective against Aspergillus strains, which remains a major problem due to the high rate of mortality associated with invasive aspergillosis. New drugs that are effective against both
Candida and Aspergillus have been developed; in particular, posaconazole seems to be a promising agent for stem cell transplant patients with graft versus host disease (GVHD), and many hospitals in the US and Europe regularly use this drug [6]. Posaconazole has recently been introduced to Turkey and the other candidate azole voriconazole is not indicated for prophylaxis. The present study aimed to determine the current state of antifungal prophylaxis in Turkish SCT centers. The survey will be repeated in 3 years to monitor any changes in antifungal prophylactic practice following the introduction of new antifungal drugs.

\section{Materials and Methods}

A survey questionnaire was used to collect data on the type of center, type of transplants performed, drugs and doses used for antifungal prophylaxis, and prophylactic strategies. Among the 38 SCT centers in Turkey, 28 were registered with EBMT (Figure 1). All 28 centers received the questionnaire, which was confirmed by phone, fax, or e-mail. In all, 24 centers responded to the survey; 1 of the 24 centers was excluded from the study, as it was under construction at the time and was not performing transplantation.

\section{Results}

\section{Center characteristics}

In all, $15(65 \%)$ of the 23 centers were adult SCT centers, 7 (31\%) were pediatric SCT centers, and 1 
center treated both adult and pediatric patients (Figure 2). All centers (23/23) performed both allogeneic and autologous transplants, 20 centers performed non-myeloablative transplants, 8 performed cord blood transplants, and 7 performed unrelated transplants.

\section{Prophylaxis strategies}

Primary antifungal prophylaxis was used at all 23 centers during allogeneic transplantation, whereas 18 of the 23 centers used it during all autologous transplants and 2 of the 23 centers used it during autologous transplants on a per case basis. The most common drug used for prophylaxis was $\mathrm{F}$ (21/23), followed by itraconazole (I) (3/23), amphotericin-B (2/23), and posaconazole (1/23). For autologous transplants the most common prophylactic drug was $F(18 / 20)$, followed by I (3/20), and amphotericin-B (2/20) (Table 1).

\section{Dose}

The median $\mathrm{F}$ dose was $400 \mathrm{mg} / \mathrm{d}$ for allogeneic transplants and $225 \mathrm{mg} / \mathrm{d}$ for autologous transplants.

\section{Duration}

Primary prophylaxis most commonly began on $\mathrm{d}$ $0(-6$ and +1$)$ and ended on $d 90(+30-180)$ in the absence of GVHD. In patients with GVHD, the last day of prophylaxis was d 180 (60->180). For autologous transplants prophylaxis began on d 0 ( -1 and $+1)$ and ended on d $30(+15-180)$.

\section{Change of Approach}

Among the 23 centers, 3 reported that for allogenic transplants they changed the antifungal prophylactic in cases of GVHD, and 12 (52\%) of the 23 (52\%) centers reported that they changed the antifungal prophylactic in case of nearby construction. All 23 centers performed secondary prophylaxis and voriconazole was used most often (17.5\%), followed by amphotericin-B (7.2\%).

\section{Diagnosis}

For diagnosis of breakthrough fungal infections 21 of the 23 centers used high-resolution computed tomography, 20 used galactomannan, 5 used b-glucan, and 1 used molecular diagnostics (PCR).

\section{Physical measures}

Among the 23 centers in the study, 22 took care of the patients in private rooms, and 10 of the 23 alloge- neic and 8 of the 23 autologous centers had a laminar air flow system. In all, 22 of the 23 allogeneic centers and 21 of the 23 autologous centers used HEPA filters, and 13 of the 23 allogeneic and 11 of the 23 autologous centers had positive pressure rooms.

\section{Discussion}

Although the effectiveness of antifungal prophylaxis was established in the 1980s, in recent years there have been several new developments. It was clearly shown that $\mathrm{F}$ prophylaxis was effective in reducing the number of invasive fungal infections

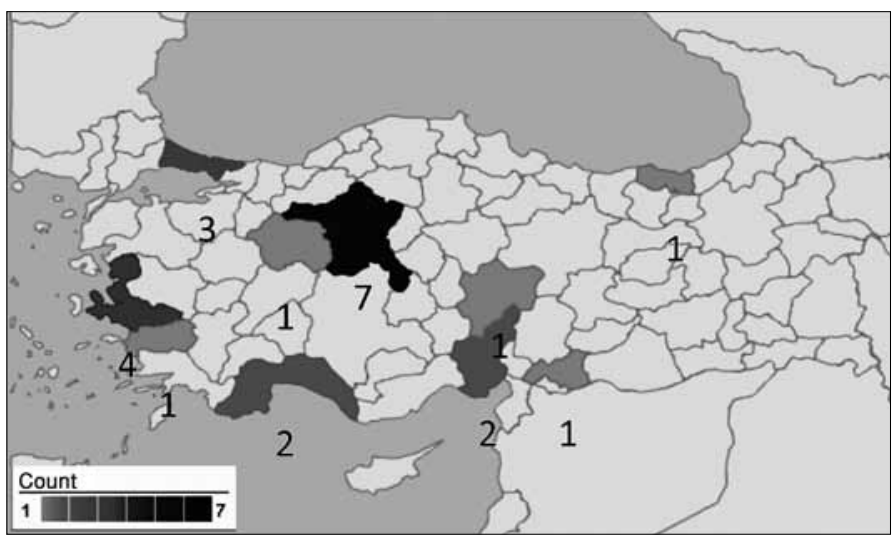

Figure 1. Distribution of Stem Cell Transplantation Centers

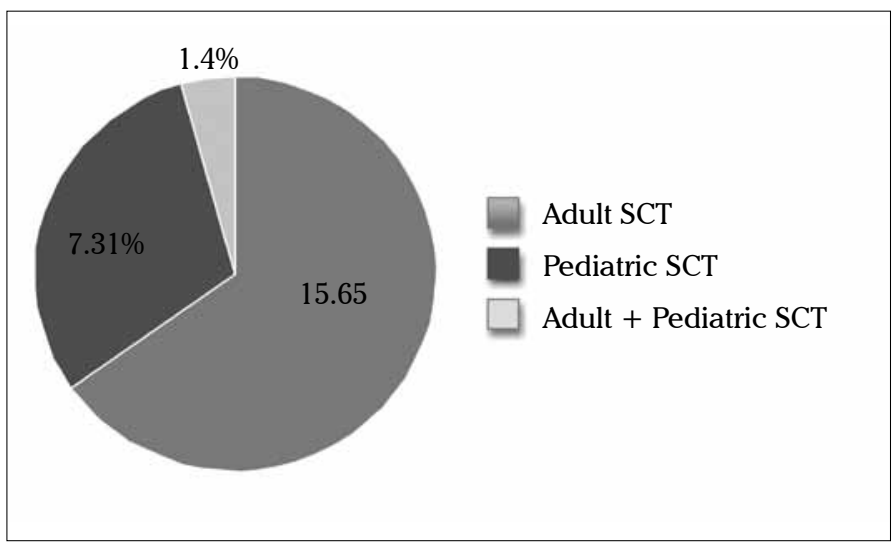

Figure 2. Type of Stem Cell Transplantation Centers

Table 1. Drugs Used in Antifungal Prophylaxis

\begin{tabular}{lcc}
\hline Type of Center & Nantiful & No. of Center/Total \\
\hline Allogeneic & Fluconazole & $21 / 23$ \\
\hline Allogeneic & Itraconazole & $3 / 23$ \\
\hline Allogeneic & Amphotericin-B & $2 / 23$ \\
Allogeneic & Posaconazole & $1 / 23$ \\
Autologuos & Fluconazole & $18 / 20$ \\
Autologous & Itraconazole & $3 / 20$ \\
Autologous & Amphotericin-B & $2 / 20$ \\
\hline
\end{tabular}


and the mortality rate in SCT patients [4,5]. These findings prompted the widespread use of $\mathrm{F}$ prophylaxis. The use of $\mathrm{F}$ led to a decrease in the number of Candida infections, which was subsequently followed by an increase in the number of Aspergillus infections [1]. The main problem was that $\mathrm{F}$ has no effect on Aspergillus and Aspergillus infection is associated with a very high mortality rate in SCT patients [1,2,7-9]. The need for an antifungal drug with a wider spectrum of effect led to the use of I prophylaxis in SCT, with some success; however, bioavailability and tolerability issues precluded its use as a primary agent for prophylaxis in SCT [10-12].

A study published in 2005 reported that posaconazole, a new triazole, was an effective prophylactic against GVHD in allogeneic SCT patients [6]. Subsequently, major treatment guidelines supported the use of posaconazole in SCT with an A1 level recommendation, and use of this approach continues to increase [13]. Voriconazole may also be a good alternative, as it is available in oral form and 2 recent studies reported its use resulted in decreasing the rate of invasive fungal infection, although it did not decrease the mortality rate. Furthermore, posaconazole in tablet form, rather than oral suspension, is currently under investigation. In Turkey $\mathrm{F}$ is the primary prophylactic drug used in SCT. Although a widespread switch to posaconazole is expected, as it was introduced to the Turkish market during the last quarter of 2010, the present study could not measure its affect on antifungal prophylactic treatment in Turkey.

All responding SCT centers are using secondary prophylaxis with voriconazole, largely due to its demonstrated effectiveness against aspergillosis and oral form. It is noteworthy that most centers rely on diagnostic measures rather than empirical approach for detecting breakthrough invasive fungal infections. The aim of the present study was to evaluate the state of antifungal prophylaxis in SCT centers in Turkey and the affect of forthcoming changes in this area will be assessed by repeating the survey in the future.

\section{Acknowledgement}

This is an observational study and does not require an Ethical committee approval. My conflict of interests are summarized below:

Clinical Research: MS\&D, Pfizer

Speaker: MS\&D, Pfizer, Gilead

Advisory Board: MS\&D

\section{References}

1. Marr KA, Carter RA, Boeckh M, Martin P, Corey L. Invasive aspergillosis in allogeneic stem cell transplant recipients: changes in epidemiology and risk factors. Blood 2002;100:4358-66. [CrossRef]

2. Pagano L, Caira M, Nosari A, Van Lint MT, Candoni A, Offidani M, Aloisi T, Irrera G, Bonini A, Picardi M, Caramatti C, Invernizzi R, Mattei D, Melillo L, de Waure C, Reddiconto G, Fianchi L, Valentini CG, Girmenia C, Leone G, Aversa F. Fungal infections in recipients of hematopoietic stem cell transplants: results of the SEIFEM B-2004 study--Sorveglianza Epidemiologica Infezioni Fungine Nelle Emopatie Maligne. Clin Infect Dis 2007;45:1161-70. [CrossRef]

3. Lin SJ, Schranz J, Teutsch SM. Aspergillosis case-fatality rate: systematic review of the literature. Clin Infect Dis 2001;32:358-66. [CrossRef]

4. Goodman JL, Winston DJ, Greenfield RA, Chandrasekar PH, Fox B, Kaizer H, Shadduck RK, Shea TC, Stiff P, Friedman DJ. A controlled trial of fluconazole to prevent fungal infections in patients undergoing bone marrow transplantation. N Engl J Med 1992;326:845-51. [CrossRef]

5. Slavin MA, Osborne B, Adams R, Levenstein MJ, Schoch HG, Feldman AR, Meyers JD, Bowden RA. Efficacy and safety of fluconazole prophylaxis for fungal infections after marrow transplantation--a prospective, randomized, double-blind study. J Infect Dis 1995; 171:1545-52. [CrossRef]

6. Ullmann AJ, Lipton JH, Vesole DH, Chandrasekar P, Langston A, Tarantolo SR, Greinix H, Morais de Azevedo W, Reddy V, Boparai N, Pedicone L, Patino H, Durrant $\mathrm{S}$. Posaconazole or fluconazole for prophylaxis in severe graft-versus-host disease. $\mathrm{N}$ Engl J Med 2007;356:335-47. [CrossRef]

7. Wingard JR, Hsu J, Hiemenz JW. Hematopoietic Stem Cell Transplantation: An Overview of Infection Risks and Epidemiology. Hematol Oncol Clin N Am 2011;25: 101-16. [CrossRef]

8. Kontoyiannis DP, Marr KA, Park BJ, Alexander BD, Anaissie EJ, Walsh TJ, Ito J, Andes DR, Baddley JW, Brown JM, Brumble LM, Freifeld AG, Hadley S, Herwaldt LA, Kauffman CA, Knapp K, Lyon GM, Morrison VA, Papanicolaou G, Patterson TF, Perl TM, Schuster MG, Walker R, Wannemuehler KA, Wingard JR, Chiller TM, Pappas PG. Prospective surveillance for invasive fungal infections in hematopoietic stem cell transplant recipients, 2001-2006: overview of the Transplant-Associated Infection Surveillance Network (TRANSNET) Database. Clin Infect Dis 2010;50:1091-100. [CrossRef]

9. Martino R, Subirá M, Rovira M, Solano C, Vázquez L, Sanz GF, Urbano-Ispizua A, Brunet S, De la Cámara R; alloPBSCT Infectious/Non-infectious Complications Subcommittees of the Grupo Español de Trasplante Hematopoyético (GETH). Invasive fungal infections after allogeneic peripheral blood stem cell transplanta- 
tion: incidence and risk factors in 395 patients. $\mathrm{Br} \mathrm{J}$ Haematol 2002;116:475-82. [CrossRef]

10. Winston DJ, Maziarz RT, Chandrasekar PH, Lazarus HM, Goldman M, Blumer JL, Leitz GJ, Territo MC. Intravenous and oral itraconazole versus intravenous and oral fluconazole for long-term antifungal prophylaxis in allogeneic hematopoietic stem-cell transplant recipients. A multicenter, randomized trial. Ann Intern Med 2003;138:705-13.

11. Harousseau JL, Dekker AW, Stamatoullas-Bastard A, Fassas A, Linkesch W, Gouveia J, De Bock R, Rovira M, Seifert WF, Joosen H, Peeters M, De Beule K. Itraconazole oral solution for primary prophylaxis of fungal infections in patients with hematological malignancy and profound neutropenia: a randomized, double-blind, double-placebo, multicenter trial comparing itraconazole and amphotericin B. Antimicrob Agents Chemother 2000;44:1887-93. [CrossRef]
12. Menichetti F, Del Favero A, Martino P, Bucaneve G, Micozzi A, Girmenia C, Barbabietola G, Pagano L, Leoni P, Specchia G, Caiozzo A, Raimondi R, Mandelli F. Itraconazole oral solution as prophylaxis for fungal infections in neutropenic patients with hematologic malignancies: a randomized, placebo-controlled, double-blind, multicenter trial. GIMEMA Infection Program. Gruppo Italiano Malattie Ematologiche dell' Adulto. Clin Infect Dis 1999;28:250-5. [CrossRef]

13. Freifeld AG, Bow EJ, Sepkowitz KA, Boeckh MJ, Ito JI, Mullen CA, Raad II, Rolston KV, Young JA, Wingard JR, Infectious Diseases Society of America. Clinical Practice Guideline for the Use of Antimicrobial Agents in Neutropenic Patients with Cancer: 2010 Update by the Infectious Diseases Society of America. Clin Infect Dis 2011;52:427-31. [CrossRef] 